\title{
Erythema Nodosum During Adalimumab Therapy: An Idiopathic Transient Paradoxical Effect
}

\author{
Ilker Ilhanli ${ }^{1}$ *, Yunus Durmaz ${ }^{2}$, Necip Guder ${ }^{3}$, KIvanc Cengiz $^{2}$ \\ ${ }^{1}$ Department of Physical Medicine and Rehabilitation, School of Medicine, Giresun University, Giresun, Turkey \\ ${ }^{2}$ Department of Physical Medicine and Rehabilitation, Division of Rheumatology, School of Medicine, Cumhuriyet University, Sivas, Turkey \\ ${ }^{3}$ Physical Medicine and Rehabilitation State Hospital, Giresun, Turkey
}

Email address:

ilkerilhanli@hotmail.com (I. Ilhanli)

\section{To cite this article:}

Ilker Ilhanli, Yunus Durmaz, Necip Guder, Kivanc Cengiz. Erythema Nodosum During Adalimumab Therapy: An Idiopathic Transient Paradoxical Effect. American Journal of Internal Medicine. Vol. 3, No. 5, 2015, pp. 210-212. doi: 10.11648/j.ajim.20150305.13

\begin{abstract}
Contrary to their undoubted efficacy on rheumatologic diseases, potential for developing skin lesions with Tumor necrosis alpha blockers (Anti-TNF alpha) is an important question in our minds. Although we know, most of the studies and case reports in the literature show that adalimumab is an effective treatment agent on erythema nodosum, we should keep in mind this lesion as a rare paradoxical side-effect. Here we present a case of idiopathic transient erythema nodosum during adalimumab therapy.
\end{abstract}

Keywords: Anti-TNF Alpha, Adalimumab, Rheumatoid Arthritis, Erythema Nodosum

\section{Introduction}

Biological agents have dramatically changed the prognosis and the therapy of the rheumatic diseases in recent years. Anti-TNF alpha therapy has had a remarkable effect on disease activity in an increasing number of rheumatic diseases, incluiding rheumatoid arthritis [1-3], juvenil idiopathic arthritis [4], ankylosing spondylitis [5-6] and psoriatic arthritis [7].

Many dermatological findings have been reported in clinical trials, including urticaria, rash, and stomatitis like during infliximab therapy [8], and injection-site reactions like during adalimumab therapy [3-9] and etanercept therapy [2].

More severe cutaneous reactions, such as bullous skin lesions, erythema multiforme, discoid and subacute cutaneous lupus erythematosus, atopic dermatitis, and necrotizing vasculitis, have been declared, mostly as single case reports [10-15]. Erythema nodosum due to anti-TNF alpha therapy is one of them [16]. Here we present a case of erythema nodosum during adalimumab therapy of a patient who was diagnosed as rheumatoid arthritis.

\section{Case}

48 years old female patient who was diagnosed as rheumatoid arthritis 20 years ago, was started to use etanercept $50 \mathrm{mg}$ per week ( 2 injections per week; trademark had only subcutan $25 \mathrm{mg}$ form of etanercept in the market) 2 years ago, while she was using methotrexate, sulfasalazine, hydroxychloroquine and meloxicam. She also had asthma and was using inhaler steroids.

The clinical and laboratory disease activity was supressed by etanercept. After 1 year of etanercept threapy, she complained from having 2 injections per week, so for patients compliance, $40 \mathrm{mg}$ adalimumab threapy (one injection per week) was started instead of etanercept. After 5 th injection ( 2 months after the switch) of adalimumab the patient admitted to our clinic with painful, red-purple colored cutaneous lesions, especially at lower limbs (Fig 1.). History of infection, drug usage and presence signs and symptoms of Behcet's disease, inflamatory bowel disease and sarcoidosis were asked and she was investigated with chest roentgenogram, endoscopy, patergy test and multiple laboratory tests including hepatitis and tuberculosis. They were all negative. We excluded streptococcal infection, because there was no clinical or laboratory finding (including faucal culture) of any infection and also, we know that erythema nodosum due to streptococcal infections is common in childhood, but in adults main causes are medications, sarcoidosis and inflammatory bowel diseases. Also, we found no evidence for malignancies or other systemic diseases. 


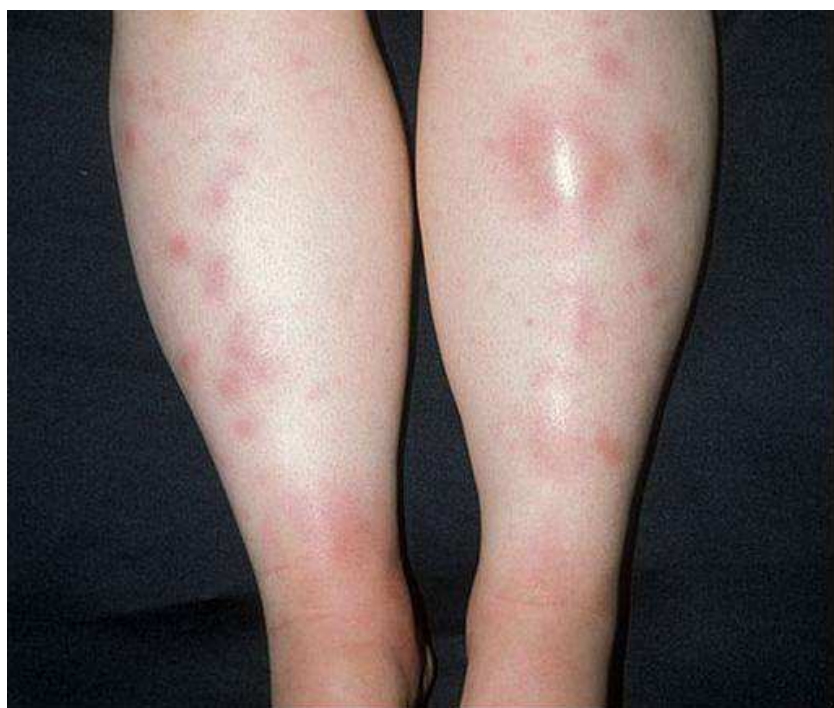

Fig. 1. Erythema nodosum on lower limbs.

Adalimumab threapy was stoped and she was observed for a month. Cutaneous lesions disappeared in 1 month. Disease activity was still supressed. Then we started adalimumab threapy again. No new cutaneous lesions appeared during the follow-up period of 5 years.

\section{Discussion}

Some dermatological manifestations of rheumatoid arthritis are rheumatoid nodules, vasculitis, palmar erythema, purpuric skin lesions, pustuler panniculitis, and livedo reticularis $[16,17]$.

Adalimumab is a human recombinant immunoglobulin G1 monoclonal antibody specific for human TNF alpha. It has a low immunogenicity potential and it binds to TNF alpha, preventing this cytokine from reaching the p55 and p75 receptors [18].

The most frequent side-effect of adalimumab is cutaneous reaction at the injection site [19]. This has been reported in $20.9 \%$ of patients taking $40 \mathrm{mg}$ adalimumab once a week. These are erythema, itching, haemorrhage, pain and swelling. Also patients may present with headache, fever, hypertension and sinusitis at the first hours of adalimumab administration [20]. It has been reported that $0.3 \%$ of patients taking adalimumab develop a cutaneous toxicity, the most frequent types are cellulitis, erysipelas or herpes zoster [19]. Other reported side-effects of adalimumab are eczematous reactions, psoriasis and psoriasiform eruption, lymphomatoid papulosis, erythema multiforme, vasculitis, rosacea, folliculitis, fungal infections, actinic keratosis, squamous cell carcinoma, basal cell carcinoma, and low grade basalioma [16,21]. Delle Sedie et al. reported psoriasis, erythema nodosum and nummular eczema in a patient using infliximab [22]. Flendrie et al. reported a case with erythema nodosum under etanercept therapy in their prospective study with 289 rheumatoid arthritis patients using TNF alpha blocking therapy [16]. We should keep in mind these rare paradoxical side-effects [23-25].
As we know, most of the studies and case reports in the literature show that adalimumab is an effective treatment agent on erythema nodosum [24-29]. Contrary to these findings, we think that our case is the first report of idiopathic transient erythema nodosum during adalimumab therapy. It is a very effective drug, but we consider that all dermatological sideeffects should be evaluated to avoid diagnostic delays after excluding the common causes of lesions.

\section{References}

[1] Lipsky PE, van der Heijde DM, St Clair EW, et al. Infliximab and methotrexate in the treatment of rheumatoid arthritis.Anti-Tumor Necrosis Factor Trial in Rheumatoid Arthritis with Concomitant Therapy Study Group. N Engl J Med 2000; 343: 1594-1602.

[2] Moreland LW,Schiff MH, Baumgartner SW, et al. Etanercept therapy in rheumatoid arthritis. A randomised, controlled trial. Ann Intern Med 1999; 130: 478-486.

[3] Weinblatt ME, Keystone EC, Furst DE, et al. Adalimumab, a fully human anti-tumor necrosis factor alpha monoclonal antibody, for the treatment of rheumatoid arthritis in patients taking concomitant methotrexate: the ARMADA trial. Arthritis Rheum 2003; 48: 35-45.

[4] Lovell DJ, Giannini EH, Reiff A, et al. Long-term efficacy and safety of etanercept in children with polyarticular-course juvenile rheumatoid arthritis: results from an ongoing multicenter, open-label, extended-treatment trial. Arthritis Rheum 2003; 48: 218-226.

[5] Brandt J, Khariouzov A, Listing J, et al. Six-month results of a double-blind, placebo-controlled trial of etanercept treatment in patients with active ankylosing spondylitis. Arthritis Rheum 2003; 48: 1667-1675.

[6] Braun J, Brandt J, Listing J, et al. Treatment of active ankylosing spondylitis with infliximab: a randomised controlled multicentre trial. Lancet 2002; 359: 1187-1193.

[7] Mease PJ, Goffe BS, Metz J, Vanderstoep A, Finck B, Burge DJ. Etanercept in the treatment of psoriatic arthritis and psoriasis: a randomised trial. Lancet 2000; 356: 385-390.

[8] Maini R, St Clair EW, Breedveld F, et al. Infliximab (chimeric anti-tumor necrosis factor alpha monoclonal antibody) versus placebo in rheumatoid arthritis patients receiving concomitant methotrexate: a randomised phase III trial. ATTRACT Study Group. Lancet 1999; 354: 1932-1939.

[9] Keystone EC, Kavanaugh AF, Sharp JT, et al. Radiographic, clinical, and functional outcomes of treatment with adalimumab (a human anti-tumor necrosis factor monoclonal antibody) in patients with active rheumatoid arthritis receiving concomitant methotrexate therapy: a randomised, placebo-controlled, 52-week trial. Arthritis Rheum 2004; 50: $1400-1411$.

[10] Bleumink GS, ter Borg EJ, Ramselaar CG, Stricker BHC. Etanercept-induced subacute cutaneous lupus erythematosus. Rheumatology 2001; 40: 1317-1319.

[11] Brion PH, Mittal HA, Kalunian KC. Autoimmune skin rashes associated with etanercept for rheumatoid arthritis (letter). Ann Inter Med 1999; 131: 634. 
[12] Kent PD, Davis JM, Davis MDP, Matteson EL. Bullous skin lesions following infliximab infusion in a patient with rheumatoid arthritis. Arthritis Rheum 2002; 46: 2257-2258.

[13] Misery L, Perrot JL, Gentil PA, Pallot PB, Cambazard F, Alexandre C. Dermatological complications of etanercept therapy for rheumatoid arthritis. Br J Dermatol 2002; 146: 334-335.

[14] Vergara G, Silvestre JF, Betlloch I, Vela P, Albares MP, Pascual JC. Cutaneous drug eruption to infliximab: Report of 4 cases with an interface dermatitis pattern. Arch Dermatol 2002; 138: 1258-1259.

[15] Wright RC. Atopic dermatitis-like eruption precipitated by infliximab. J Am Acad Dermatol 2003; 49: 160-161.

[16] Flendrie M, Vissers W, Creemers M, Jong E, Kerkhof P, Riel P. Dermatological conditions during TNF-alpha-blocking therapy in patients with rheumatoid arthritis: a prospective study. Arthritis Res Ther 2005; 7: 666-676.

[17] Goodfield MJD, Jones SK, Veale DJ. The connective tissue diseases. Textbook of Dermatology, Vol. 2, 7th edn. Blackwell Science, Oxford, 2004; 56: 138-140.

[18] Scheinfeld N. Adalimumab: a review of side effects. Expert Opin Drug Saf 2005; 4: 637-641.

[19] Scheinfeld N. A comprehensive review and evaluation of the side effects of the tumor necrosis factor alpha blockers etanercept, infliximab and adalimumab. J Dermatolog Treat 2004; 15: 280-294.

[20] Saripalli YV, Gaspari AA. Focus on biologics that affect therapeutic agents in dermatology: J Drugs Dermatol 2005; 4: 233-245.
[21] Beuthien W, Mellinghoff H-U, von Kempis J. Skin reaction to Adalimumab. Arthritis Rheum 2004; 50: 1690-1692.

[22] Delle Sedie A, Bazzichi L, Bpmbardieri S, Riente L. Psoriasis, erythema nodosum, and nummular eczema onset in an ankylosing spondylitis patient treated with infliximab.Scand $\mathrm{J}$ Rheumatol 2007; 36(5): 403-404.

[23] Rajakulendran S, Deighton C. Adverse dermatological reactions in rheumatoid arthritis patients treated with etanercept, an anti-TNFalpha drug. Curr Drug Saf 2006; 1(3): 259-264.

[24] Zippi M, Pica R, De Nitto D, Paoluzi P. Biological therapy for dermatological manifestations of inflammatory bowel disease. World J Clin Cases 2013; 1(2): 74-78.

[25] Dalmau-Carolà J. Erythema nodosum, a "red flag" during anti-TNF therapy. Int J Rheum Dis 2013; 16(4): 493-494.

[26] Tanida S, Inoue N, Kobayashi K, et al. Adalimumab for the treatment of Japanese patients with intestinal Behçet's disease. Clin Gastroenterol Hepatol 2015; 13(5): 940-948.

[27] Benítez-Gutiérrez L, Tutor-de Ureta P, Mellor-Pita S, YebraBango M. Refractory chronic erythema nodosum treated with adalimumab. Rev Clin Esp (Barc) 2013; 213(9): 466-467. [Article in Spanish]

[28] Ortego-Centeno N, Callejas-Rubio JL, Sanchez-Cano D, Caballero-Morales T. Refractory chronic erythema nodosum successfully treated with adalimumab. J Eur Acad Dermatol Venereol 2007; 21(3): 408-410.

[29] Quin A, Kane S, Ulitsky O. A case of fistulizing Crohn's disease and erythema nodosum managed with adalimumab.Nat Clin Pract Gastroenterol Hepatol 2008; 5(5): 278-281. 